\title{
TAXONOMY OF THE GENUS COLUMBA
}

\author{
By D. GOODWIN
}

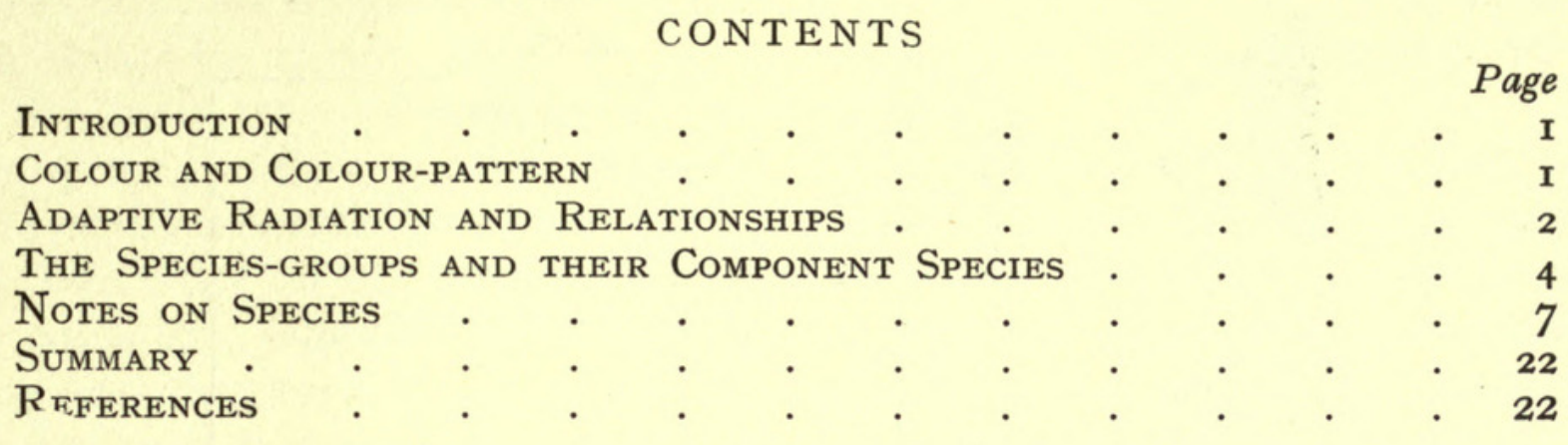

SYNOPSIS

Previous reviews of the genus Columba have grouped together species which lack display plumage on the neck or whose ornamentation is superficially similar. This is believed to have resulted in some false conclusions because such display plumage has been independently lost or become obsolescent in several species. When this is recognized and greater importance attached to basic colour-patterns and geographical distribution a truer picture of relationships within the genus can be arrived at.

\section{INTRODUCTION}

THE genus Columba includes a large number of medium to large-sized pigeons, widely distributed throughout the world. Peters (I937), for example, lists fifty-two species and does not divide them into sub-genera. The rather inconveniently large size of the genus has often been criticized and the affinities of its members questioned. Ridgway (Igr6) separated the relatively few northern and central American species into six genera, some of them monotypic. The most important recent revision of the genus is that of Boetticher (I954), who divides it into several sub-genera and corrects some false conclusions of a previous and less comprehensive revision by MiculiczRadecki (I949).

When re-arranging the very extensive collection of specimens of Columba in the British Museum (Natural History) it was found impossible to agree with all of Boetticher's conclusions. The object of this paper, therefore, is a revision of the genus based on examination of the skins in the National Collection and correlated, as far as has been possible, with what is known of the ecology and behaviour of the species of which it is comprised. Emphasis is placed on discussion of those points where my conclusions differ from those of Boetticher. I am indebted to Dr. Dean Amadon of the American Museum of Natural History for the loan of specimens of Columba albinucha and C. pallidiceps, to Mr. J. D. Macdonald for help and constructive criticism and to Dr. G. Bodenstein, Professor W. F. Hollander and Mr. R. W. Sims for information and discussion on various points.

\section{COLOUR AND COLOUR-PATTERN}

Within Columba plumage colour ranges from entirely black, with green and purple iridescence, to predominantly pale grey or purplish-chestnut. It is evident that, zooL. 6, I. 
as in Ptilinopus (Cain, I954) colour-pattern is usually a better guide to relationship than actual colour. One finds striking differences in the colour of the plumage and/ or soft parts of the head and neck (the focal area of both sexual attraction and aggressive attack in pigeons) between pairs of sympatric and very closely related species as $C$. squamosa and $C$. leucocephala or $C$. rupestris and $C$. leuconota (see Text-fig. I).

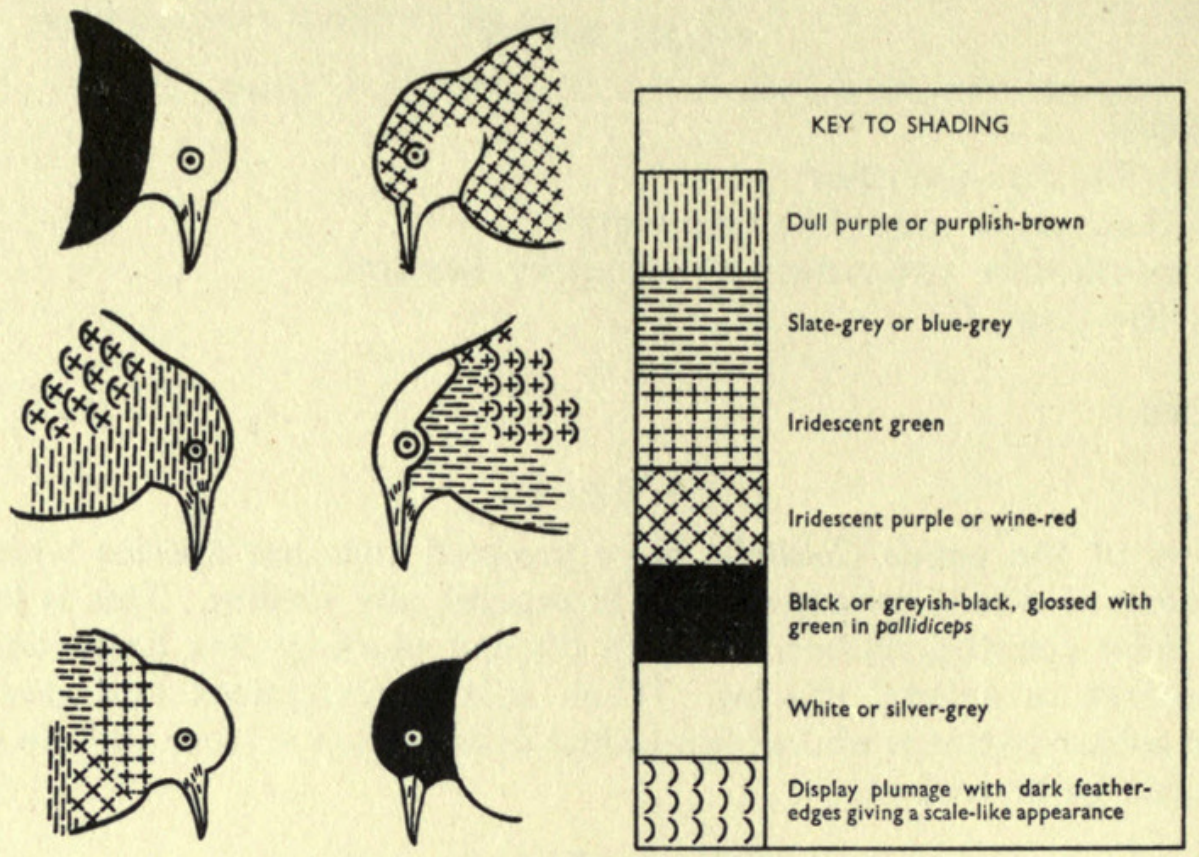

FIG. I. Diagrammatic sketches to show differences in head and neck colours between three pairs of sympatric and closely related species. From top left: pallidiceps and vitiensis, squamosa and leucocephala, rupestris and leuconota.

Such differences almost certainly function as isolating mechanisms to inhibit interspecific pairing. Signal markings on wings and tail and specific differences in voice and display-flight serve the same purpose at "longer range ". As with other groups of birds the greatest diversity of signal markings, display plumage and voice is found where there are many related and at least potentially sympatric species and, conversely, a tendency to lose such characters and acquire a dull uniformly coloured plumage in isolated island forms. Lack of signal markings or display plumage in Columba seems never to be a primitive character. Examination of the colourpattern and other characters of the species concerned shows convincingly that their common lack of ornamentation is due to convergence and not to close affinity.

Sexual dimorphism in Columba is relatively slight but in most species it is sufficient to enable skins or living birds to be correctly sexed on plumage colour alone. In those species which are predominantly grey males are a purer, bluer grey than females. Purple, chestnut or mauve-pink in males is often duller, absent. or replaced by dull brown in females. Iridescent display plumage (when present) is usually more brilliant in males. Where adults show such differences of plumage similar and homologous sexual differences are found in the juvenile plumage.

\section{ADAPTIVE RADIATION AND RELATIONSHIPS}

Adaptive radiation can be misleading at generic level, since once two forms have evolved marked differences of size and structure they are unlikely to be considered 
con-generic. For example the many Australian bronze-wing pigeons are obviously very close relatives in spite of the taxonomically convenient differences in size and proportions which they have developed in the course of adaptation to different ecological niches. Within Columba, as here recognized, the greatest amount of adaptive radiation is found among the Palearctic and Ethiopian species. Similar, but less marked differences are shown among the American species, but here maculosa, which otherwise closely parallels the old-world livia, has not emancipated itself from the use of trees for resting and breeding.

The question arises whether the New World representatives of Columba should be generically separated from the Old World forms. Cumley \& Irwin (I944) concluded from their work on the antigenic inter-relationships of the blood cells of guinea, livia, palumbus, janthina, fasciata, maculosa, picazuro, cayennensis, flavirostris and leucocephala that each of the six American species was more closely related to the other five than to any of the four Eurasian species. Verheyen (I957) considers that skeletal differences warrant the separation of Old and New World forms of Columba, both of which groups he further divides into several genera, some of them monotypic. I am not competent to criticize Verheyen's opinions in so far as they are based on osteology, but his decisions placing guinea in the monotypic genus Dialiptila and generically separating janthina, vitiensis and norfolciensis are so contrary to the evidence from external taxonomic characters and behaviour-patterns that I hesitate to follow his conclusions without further evidence.

If the New World species are to be generically separated this could be done only on osteological and biochemical characters. Possibly studies currently in progress in America will show that there are constant and significant behavioural differences also and it will be desirable to separate the American from the Old World species. I think, however, that at present it would be premature to do so.

It seems to me best to retain the large genus Columba as used by Peters (I937) and Hellmayr \& Conover (I942) but to give Oenoenas and Turturoena sub-generic rank within it. I also think that Nesoenas should be given only sub-generic rank within Columba. The remaining forms can be relegated to five species-groups. Cain (1954), in his revision of the pigeons in the genus Ptilinopus, used the category of the species-group for " an informal natural group of closely related species below the rank of a subgenus, the recognition of which involves no complication of the scientific names of the species contained in it." And that of sub-group for more closely related forms within the species-group. I have followed Cain in the use of these categories which are equally useful for defining relationships of the pigeons in Columba. The hierarchy of categories is therefore :

Genus

$$
\begin{aligned}
& \text { Sub-genus } \\
& \text { Species-group } \\
& \text { Sub-groups (of species group) } \\
& \text { Superspecies } \\
& \text { Species } \\
& \text { Subspecies }
\end{aligned}
$$


There are, naturally, some species whose characters show them to be intermediate between two sub-groups and it has been necessary to allot them somewhat arbitrarily to that with which they seem to have most in common or else to place them in a mono-specific sub-group. All such cases are discussed below. In the following list members of the same superspecies are bracketed together. Subspecies have not been listed but they are discussed under the species headings where they are relevant to specific problems.

THE SPECIES-GROUPS AND THEIR COMPONENT SPECIES

\section{(I) Oenas Species-group}

Smallish (oliviae) to large (trocaz) sized columbids inhabiting the Palearctic and Ethiopian regions, one species (livia) also occurring in India, and throughout much of the world in a feral state as a result of human introduction. Most species in this group have well developed display plumage on the neck and patterned tails. Sexual dimorphism slight.

\section{(a) Palumbus Sub-group}

Tail rather long with conspicuous pale central band; breast mauve-pink or salmon-pink.

C. palumbus Linnaeus, $175^{8}$

C. trocaz Heineken, 1829

C. bollii Godman, 1872

C. unicincta Cassin, 1859 (I860)

(b) Oenas Sub-group

Glossless mauve-pink on head and/or breast, black signal markings on inner wing-coverts (obsolescent in oliviae).

C. oenas Linnaeus, 1758

$\left\{\begin{array}{l}\text { C. eversmanni Bonaparte, I856 } \\ \text { C. oliviae Stephenson Clarke, I9I } 8\end{array}\right.$

(c) Livia Sub-group

No glossless mauve-pink colour on breast or head. Display plumage on front as well as sides of neck (absent in leuconota).
$\{$ C. livia Gmelin, I789
$\{$ C. rupestris Pallas, I8II
C. leuconota Vigors, I83I
C. guinea Linnaeus, 1758
C. albitorques Rüppell I837 
(2) Junioniae Species-group

Large columbid inhabiting the western Canary Islands of Palma and Gomera. Mantle and wings dark brown and immaculate; tail with broad pale terminal band. Entire neck and breast iridescent but no well differentiated display plumage. One species C. junioniae Hartert, I9I6.

\section{(3) Elphinstonii Species-group}

Smallish medium to large-sized columbids inhabiting the Indo-malayan and Ethiopian regions. All except one with unpatterned tails. No signal markings on wings. Most with display plumage on sides and back of neck.

\section{(a) Arquatrix Sub-group}

Display plumage on hind neck lanceolate. Wing-coverts and/or underparts spotted with white (obsolescent spots in polleni).
$\{$ C. arquatrix Temmink, I809
$\{$ C. pollenii Schlegel, I866
C. hodgsonii Vigors, 1832
C. albinucha Sassi, I9II

(b) Elphinstonii Sub-group

Display plumage on hind neck of black feathers tipped white or buff. Iridescent green or purple sheen on neck and mantle. Unpatterned tails, no signal markings on wings. One superspecies.

$$
\left\{\begin{array}{l}
\text { C. pulchricollis Blyth, I845 (I846) } \\
\text { C. elphinstonii (Sykes, I832) } \\
\text { C. torringtoni Bonaparte, I854 }
\end{array}\right.
$$

\section{(c) Punicea Sub-group}

No well differentiated display plumage on neck; wing coverts and body plumage immaculate chestnut or silver contrasting with black primaries.

C. punicea Blyth, $\mathrm{I} 842$

C. argentina Bonaparte, $\mathrm{I} 855$

\section{(d) Palumboides Sub-group}

Head and neck silver-grey; wings and back dark grey with iridescent feather edges. One species.

C. palumboides (Hume, I873)

\section{(4) Janthina Species-group}

Large columbids inhabiting the Pacific regions from Japan to Australia, chiefly on islands. Plumage largely or entirely blackish and highly iridescent. No signal markings on wings; dark unpatterned tails. Not divisible into sub-groups. 


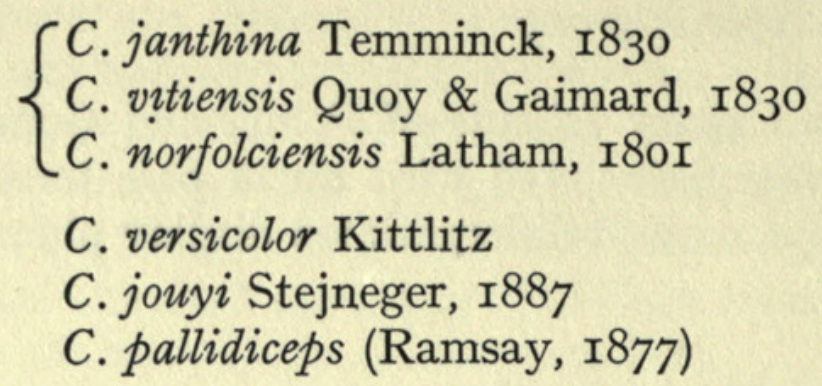

(5) Picazuro Species-group

Small (rufina) to medium-large (maculosa) columbids inhabiting the nearctic and neotropic regions. Most with display plumage on back and sides of neck and patterned tails.

(a) Leucocephala Sub-group

Patch of velvet-like feathers on nape ; well-defined iridescent display plumage on back and sides of neck. Plumage largely dark slate-grey; wings and tail unmarked.

C. leucocephala Linnaeus, I758

C. squamosa Bonnaterre, I792

(b) Speciosa Sub-group

Feathers of neck and breast white and golden with dark, iridescent edges ; back, rump and wing-coverts purplish-chestnut (male) or dark brown (female). Tail blackish and unmarked. One species only.

C. speciosa Gmelin, 1789

(c) Picazuro Sub-group

Outer wing-coverts edged white; mantle and wing-coverts brown, tail with illdefined terminal dark band.

$\{$ C. picazuro Temminck, $\mathrm{I} 8 \mathrm{I} 3$

\{C. corensis Jacquin, $\mathrm{I} 784$

C. maculosa Temminck, $\mathrm{I} 8 \mathrm{r} 3$

(d) Fasciata Sub-group

Parti-coloured tail with broad, pale terminal band. Iridescent green display plumage on hind-neck. One superspecies.

$$
\left\{\begin{array}{l}
\text { C. fasciata Say, } \mathrm{I} 823 \\
\text { C. araucana Lesson, } \mathrm{I} 827 \\
\text { C. caribaea Jacquin, } \mathrm{I} 784
\end{array}\right.
$$

(e) Rufina Sub-group

Small size. Crown and nape iridescent; ill-defined pale terminal band on tail; plumage mainly vinous-purple.

C. rufina Temminck, I8Io 
(f) Flavirostris Sub-group

No iridescence on head or neck; plumage largely vinous-purple ; tail dark grey without markings. One superspecies.

$$
\left\{\begin{array}{l}
\text { C. Alavirostris Wagler, I83I } \\
\text { C. oenops Salvin, I895 } \\
\text { C. inornata Vigors, I827 }
\end{array}\right.
$$

\section{Sub-genus Oenoenas}

Small columbids of central and southern America with dark brown and greyishpurple or reddish-purple plumage ; small bills, strongly rounded tails, obsolescent display plumage on hind neck and no markings on wings or tail. Consists of only four species. It seems purposeless to sub-divide further this small and very homogeneous assemblage into sub-groups, which could only be done, if at all, on the shorter tails of two of them, nigrirostris and goodsoni.
C. subvinacea (Lawrence, I868)
C. plumbea Vieillot, I8I8
$\left\{\begin{array}{l}\text { C. nigrirostris Sclater, I859 (I860) } \\ \text { C. goodsoni Hartert, I902 }\end{array}\right.$

\section{Sub-genus Turturoena}

Small columbids inhabiting the Ethiopian region. Bright metallic iridescence on hind-neck. Marked sexual dimorphism except in the island form malherbii. One superspecies.

$$
\left\{\begin{array}{l}
\text { C. delagorguei Delagorgue, I847 } \\
\text { C. iriditorques Cassin, I856 } \\
\text { C. malherbii } \text { Verreaux \& Verreaux, I85I }
\end{array}\right.
$$

Sub-genus Nesoenas

Large-sized Mauritian columbid with rounded wings (first primary about equal in length to sixth) and rufous tail. One species.

C. mayeri Prevost, $\mathrm{I} 843$

\section{C. palumbus}

NOTES ON SPECIES

The Wood Pigeon is considered by Boetticher (I954) to be most closely related to torringtoni, elphinstonii, trocaz and junioniae and to be much nearer to fasciata and allied American species than to oenas or unicincta. He grouped these, and some other pigeons, close together because they all show a high degree of ornamentation on the neck feathers, similar relative lengths of wing and tail and arboreal habits.

Certainly the conspicuous white or cream-coloured patches on its neck give palumbus a superficial resemblance to such species as fasciata which also have conspicuous white areas in the display plumage of the neck. In its colour-pattern and 


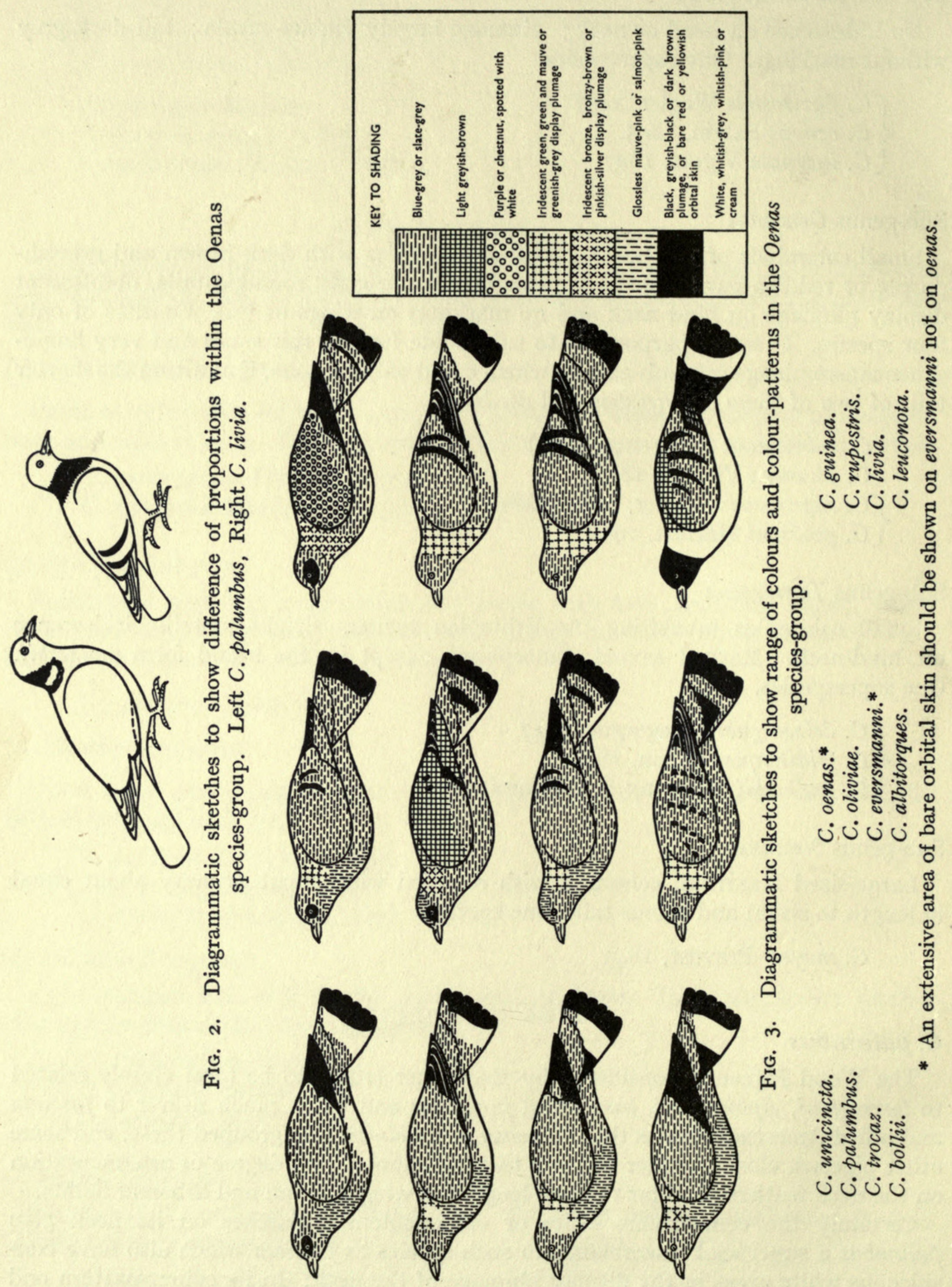


even in the individual colours, however, it agrees more closely with unicincta and oenas. The difference in coloration of the display plumage on the necks of oenas and palumbus, due to the white patches of the latter, can be interpreted as an isolating mechanism (see Sibley, I957) as can the difference in their advertising calls. The bowing display of palumbus is identical with that of oenas and its pre-copulatory behaviour is very similar to that of oenas, guinea and livia (see Goodwin, I956a) and differs from that of fasciata as described by Whitman (I9I9). It is true that in some points of structure and deportment palumbus bears more resemblance to fasciata than to oenas but this may be attributed to the fact that palumbus and fasciata are largely arboreal and obtain much of their food from the tips of slender branches whereas oenas is almost entirely a ground feeder. Geographical distribution also seems to favour the linkage of palumbus and oenas. In my opinion, and excepting obvious derivatives on the Atlantic islands (see trocaz and bollii), palumbus has closest affinities with unicincta and is nearer to oenas than it is to pulchricollis or fasciata or to their close allies. At the same time its undoubted resemblance to these latter emphasize the difficulties of generically separating the Eurasian and American groups of Columba.

\section{C. trocaz}

The Madeiran Pigeon appears to be a fairly recent derivative of palumbus. In its voice and bowing display it closely resembles that species and in appearance it differs only in its slightly darker coloration, in lacking the white signal markings on the wings and in its slightly longer legs and more sloping forehead. As, however, it would seem to have diverged sufficiently not to have interbred with later Wood Pigeon invaders, now distinguished racially as $C$. palumbus maderensis, it has to be accorded specific rank.

\section{C. bollii}

Bolle's Pigeon is considered by Peters (I937) and others to be conspecific with trocaz. Both appear to be derivatives of palumbus but evidence suggests that they did not share a common ancestry subsequent to their differentiation from the parent stock. Although both have lost the white wing patch of palumbus the white neck patch has modified in different directions in each. In trocaz it has become a dull silvery grey and increased in area whereas in bollii it has become a small glossy brown mark. Since trocaz cannot now be considered conspecific with palumbus it seems better to give bollii specific status also.

\section{C. unicincta}

Boetticher considers the Afep Pigeon to be a relatively primitive species, most closely related to maculosa, because it lacks display plumage on the neck. It seems to me much more likely that loss of display plumage has occurred at a relatively late stage in the evolution of both species and does not indicate any close phylogenetic relationship between them. In its general colour pattern unicincta agrees fairly closely with palumbus and its tail markings are identical with those of that 
species. Two features in which unicincta differs from palumbus are in its pale-edged wing-coverts and in its grey feet and bill. Since, however, these features, like the lack of iridescence on the neck, are similar to those in juveniles of palumbus I do not think they diminish the likelihood of close phylogenetic relationship of unicincta and palumbus, which their other features, including the little that has been recorded about the behaviour and ecology of unicincta, seem to indicate.

\section{C. oenas}

The Stock Dove is usually considered to be much more closely related to livia than to palumbus but in fact it forms a connecting link between the two in its taxonomic characters as well as in its ecology and behaviour (Goodwin, I956a). Thus it agrees with palumbus in the distribution of the display plumage on its neck, in its glossless mauve-pink breast and in the form of its bowing display, but its wing and tail markings and its proportions are closer to livia. In view of the intermediate position of this, the type species of Columba, generic separation of " wood pigeons" and "rock pigeons" becomes untenable.

\section{C. eversmanni}

Eversmann's Stock Dove is extremely close to oenas in appearance, differing only in its smaller size, yellow irides and in having the head as well as the breast mauvepink, or with a strong mauve-pink tinge, and in sometimes having a white instead of a grey rump. I concur with Peters in thinking that the evidence at present available warrants their both being considered full species. Stuart Baker (I928) put eversmanni as a race of oenas stating that "intermediate forms are not infrequent". He gave no evidence for this other than mentioning some grey-rumped eversmanni having been obtained in Afghanistan. Except in this one feature grey-rumped individuals do not resemble oenas any more closely than do white-rumped ones. Stuart Baker's further remarks about the affinities of the two show that he knew little about the behaviour and ecology of oenas. The breeding range of eversmanni as indicated by Dementiev et al. (I95I) has a considerable overlap with that of oenas. That they retain their respective characteristics where they are, apparently, sympatric, is evidence of their specific status.

\section{C. oliviae}

The Somaliland Pigeon can be regarded as forming a superspecies with eversmanni. The differences between them can be explained by the adaptation of oliviae to its torrid desert habitat. As well as acquiring a paler and browner coloration it has lost the black wing bars, probably quite recently, as many specimens show a few blackish flecks where these are in eversmanni. The loss of these signal markings may have resulted from a need for more perfect camouflage or simply to lack of selection for them subsequent to isolation from other closely related species. Unfortunately nothing appears to have been recorded of the behaviour or breeding habits of this species. In spite of its alternative vernacular name of "Somali Rock Pigeon", oliviae is no more closely related to livia than are eversmanni or oenas. 


\section{C. al „orques}

The White-collared Pigeon has a white neck ring like that of fasciata and acuminate neck feathers like arquatrix. But as it resembles these species in no other respects it is highly unlikely that these likenesses indicate close relationship. Its tail pattern and the black markings on its wings seem to indicate relationship to oenas and livia. Taibell (I954) describes a bowing display like that of oenas. The lack of strong contrast between the black wing markings and their dark grey background, the slight degree of iridescence of the neck feathers and the partially concealed white wing patch may indicate that albitorques is at a stage of evolution where it is beginning to lose some of its display and signal markings, presumably as a result of being now ecologically isolated from related species. On the whole the appearance and taxonomic characters of this pigeon suggest a rather closer relationship with livia and guinea than with oenas and I have, accordingly, placed it in the livia sub-group.

\section{C. guinea}

It is fairly certain that the Speckled Pigeon is a close relative of livia (see Goodwin, I956 and I956a) in spite of their differences of colour. They resemble each other in having display plumage on the front as well as on sides and back of the neck and in having the feathers of this display plumage bifurcated; there are also many close resemblances of voice and behaviour. On the evidence of the blood antigens Cumley \& Irwin showed that biochemically guinea is closer to palumbus than it is to livia or oenas. This is supported by two points of behaviour-its calls and postures immediately after copulation and its methods of fighting. Thus what is known of this species emphasizes the essential homogeneity of the oenas species-group in spite of the rather considerable, if somewhat superficial, taxonomic and behavioural variations within it. I think, however, that in sub-dividing this group guinea should be put in the same sub-group as livia.

\section{C. leuconota}

The Snow Pigeon's plumage and general habits suggest a close relationship with livia and rupestris. The great differences in colour of the head and neck between leuconota and rupestris is almost certainly to be considered as an isolating mechanism and of little importance as an indicator of phylogenetic disparity. The same may be true of the apparently considerable difference between the voice and bowing display of leuconota (Newman, I9II) and that of livia. The black and white pattern on the tail of leuconota appears different from that of livia and other allied species but is essentially similar, the differences being due to a reduction of the black terminal band and an extension of the black basal area on the outer rectrices.

\section{C. livia}

The Rock Pigeon gives an impression of standing far apart from palumbus in appearance and behaviour. Boetticher (I954) indeed puts them as the terminal twigs on the two mutually diverging main branches of his family tree of Columba. The differences of form, behaviour and coloration shown by livia are largely due 
to its adaptations to nesting and sheltering in caves and rock fissures and feeding in open tree-less country. In fact I think that livia and palumbus are fundamentally much alike and that they represent the extremes in a single rather large species-group. Although livia now occurs in some moderately wooded regions it almost certainly evolved in a treeless or almost treeless environment. Its points of resemblance to rupestris, guinea and oenas are discussed under those species.

\section{C. rupestris}

The Blue Hill Pigeon is usually accorded specific rank although Austin (I948) put it as a race of livia but without giving reasons for this decision. Over most of their range the two are allopatric, rupestris replacing livia in the higher and colder parts of central and eastern Asia. The differences between them are certainly such as suggest racial rather than specific status. Rupestris has a proportionately smaller bill and a reduced amount of melanin in the plumage resulting in a white instead of a grey central bar in the tail, smaller black wing bars, paler grey ground colour and less intensely iridescent display plumage; all differences such as might be expected in a race inhabiting a colder climate. With the possible exception of the white tail bar none of these cause as great difference in appearance as exists, for example, between $C$. livia gymnocyclus and $C . l$. dakhlae or $C . l$. livia and $C . l$. intermedia. In its habits and ecology (Schafer, I938) rupestris apparently differs in no essentials from livia.

These facts suggest that the two are conspecific. On the other hand rupestris is said to associate with livia in parts of northern India (Stuart Baker, I9I3) and it is potentially in contact with feral specimens of livia in many parts of its range. La Touche (I934) shot a specimen of $C$. livia intermedia (sic) out of a flock of rupestris in eastern China. The voice of rupestris, as described by Salim Ali (I949), would appear to differ much from that of livia. The evidence is thus conflicting. La Touche considers that the occurrence of mixed flocks suggest that rupestris and livia interbreed but this might equally well be evidence to the contrary. If, as is likely, the term " mixed flock" has been applied to aggregations of rupestris and (? feral) livia at feeding grounds then such associations are of no significance either way. There are no specimens from among the many from North India and the Himalayas in the National Collection that appear to be hybrids or intergrades between the two. It must be admitted, however, that such birds might be difficult to detect, unless they were intermediate in coloration of the tail. Until the matter can be investigated more conclusively it seems best to accept the majority opinion that rupestris is a full species. Since the evidence suggests strongly that, at least as far as genuinely wild individuals are concerned, livia and rupestris are allopatric when breeding they should, I think, be considered members of a superspecies.

\section{C. junioniae}

The coloration and size of the Laurel Pigeon suggest relationship to palumbus. On the other hand the colour-pattern of its tail is similar to that of albinucha and fasciata. Meade-Waldo (I889) described it as having a very distinctive gait when 
walking on the ground and a "soft, flopping flight " which was unlike that of any other pigeon known to him. He found that on the Island of Gomera, in the Canaries, it kept mainly to scrub-covered slopes at relatively low altitudes, being replaced in the high mountain forest by $C$. bollii. It lays one egg to a clutch. The Laurel Pigeon seems most likely to be either an offshoot from primitive palearctic Columba stock prior to its subsequent speciation or an early offshoot from palumbus. It is impossible to do more than guess at its affinities from an examination of skins and the little that has been recorded of its behaviour. A detailed comparison of its anatomical and behavioural characters with those of, at least, palumbus, fasciata and albinucha will probably be necessary before its true relationships can be ascertained.

\section{C. arquatrix}

Nominate arquatrix with a purple head, silver-grey nape and yellow bill and legs
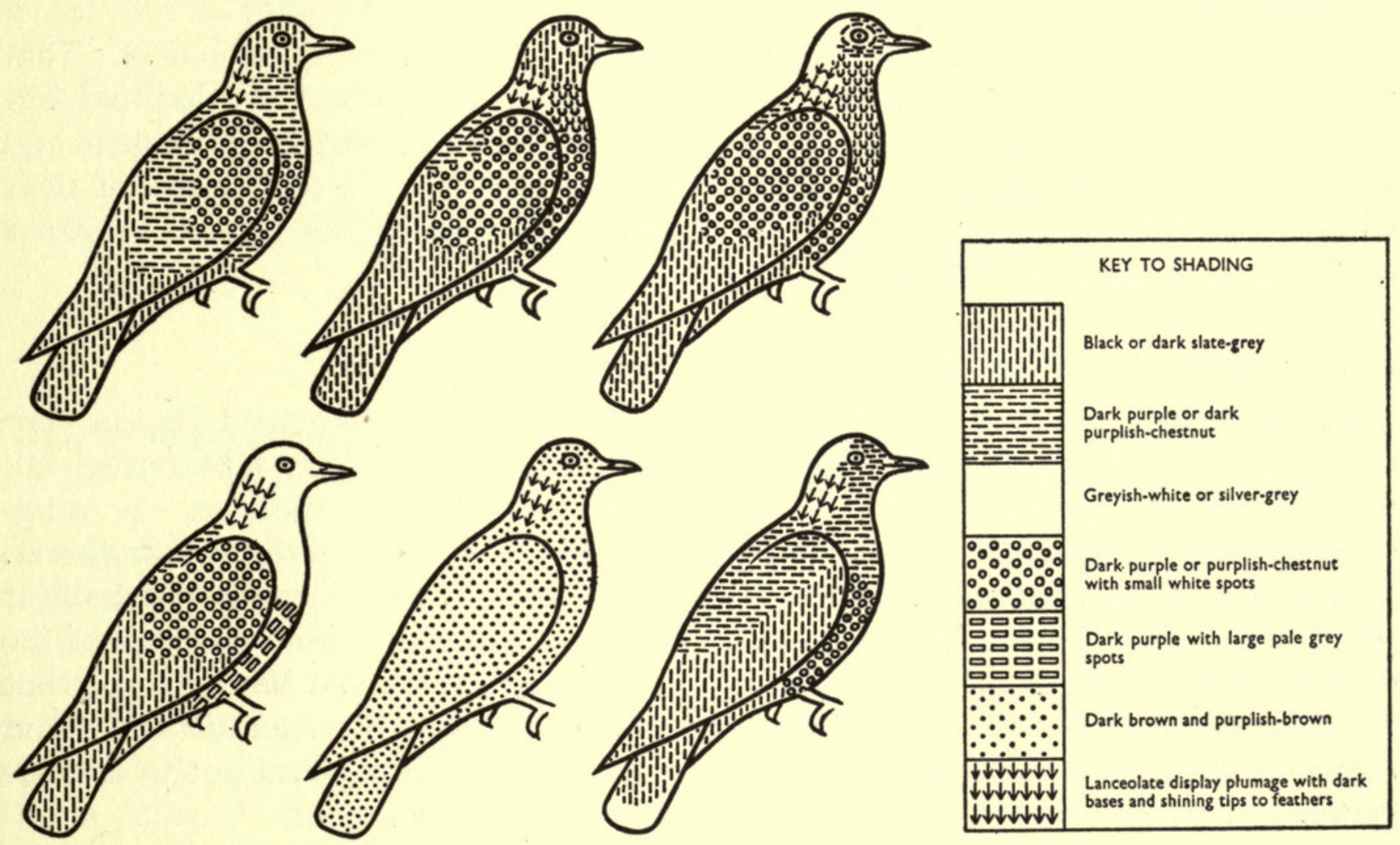

FIG. 4. Diagrammatic sketches to show colours of the Arquatrix sub-group. Left to right: a. thomensis, a. sjostedti, a. arquatrix and (bottom) hodgsoni, polleni and albinucha.

has always been considered, rightly in my opinion, conspecific with sjostedti from the Cameroon Mountains, which has an entirely dark grey head, red orange-tipped bill and dark purplish legs and feet. The Sao Thomé representative, thomensis, is, however, currently given specific rank. It should, I think, be put as a race of arquatrix. In plumage it is just a dull version of the latter with the spotting on wingcoverts and undersides and the lanceolate display plumage on the neck showing, apparently, the beginning of that obsolescence of markings that so often takes place in island forms. It otherwise shows characters of both mainland forms, having an 
entirely dark grey head like $a$. sjostedti but yellow legs and bill like $a$. arquatrix. It has a somewhat longer tail than either mainland form but this alone does not, in my opinion, warrant its specific separation from them.

\section{C. polleni*}

In spite of its almost uniform dark brown plumage polleni is also a representative of arquatrix. Although, presumably in the course of long isolation on the Comoro Islands, it has lost the rich colours of arquatrix it still retains lanceolate display plumage on the hind neck and the yellow legs and bill. Of three skins in the National Collection one shows faint pale spots on the underparts exactly similar to, though less pronounced than the spots of arquatrix. It has, however, reached a degree of differentiation from arquatrix that justifies, in my opinion, its specific rank, though it should be considered as forming a superspecies with arquatrix and hodgsoni.

\section{C. hodgsoni}

Verheyen (I955) considers this Indian species conspecific with arquatrix. That they are geographical representatives of the same stock cannot be doubted but hodgsoni differs from arquatrix in several minor points of coloration of plumage and soft parts and in its much greater sexual dimorphism. In view of this and of their wide geographic separation I think it is better to give them specific rank as members of the same superspecies.

\section{C. albinucha}

In coloration, colour-pattern and display plumage the White-naped Pigeon very closely resembles arquatrix. It differs in having red bill and feet, a patterned tail with conspicuous pale terminal bar and in lacking the white spots on the wingcoverts, although its underparts are spotted in the same manner as those of arquatrix. It is also a little smaller. The two are sympatric but their ecology and habitat preferences differ (Van Someren, I949). Nothing seems to have been recorded of the displays, nesting or clutch-size of albinucha. Although there can be no doubt that they should be regarded as good species, the resemblances between albinucha and arquatrix are almost certainly due to close phylogenetic affinity and not to convergence.

\section{C. elphinstonii, C. pulchricollis and C. torringtoni}

Although differing in size and coloration these three forms all resemble each other in colour-pattern, form of display plumage and (so far as is recorded) in habits and ecology. It is difficult to decide whether it is best to treat them as races of a single

* Through the kindness of Mr. C. W. Benson I have recently been able to examine the fine series of polleni collected on the B. O. U. Centenary Expedition to the Comoro Islands. These specimens show that the unsexed skins I had previously seen were all females and all somewhat "foxed". In fact males are a brownish purple on head, upper mantle and breast and the dark brown parts of both sexes are suffused with grey, especially on the rump. They thus resemble arquatrix more closely than I had thought and Mr. Benson informs me that the calls of the two are similar; possibly identical. I, therefore, now consider that polleni should be treated as a race of arquatrix and not as a separate species. 
species or as members of a superspecies. Their ranges nowhere overlap and they have, presumably, been long isolated from contact with each other. As they have always been accorded specific rank it seems to me best to regard them as members of a superspecies.

\section{C. punicea}

The Purple Wood Pigeon most closely resembles argentina in colour-pattern although its purplish-chestnut body colour gives it a very different superficial appearance. This species is said sometimes to lay one and sometimes two eggs per clutch (Stuart Baker, I9I3). If this is really the case-no one other than Stuart Baker appears to have found nests with more than one egg - this is an interesting intermediate condition between the species laying one egg and those laying two.

\section{C. argentina}

The Silver Pigeon shows a striking resemblance to the Pied Imperial Pigeons in colour and colour-pattern. Boetticher (I954) considered it more closely related to
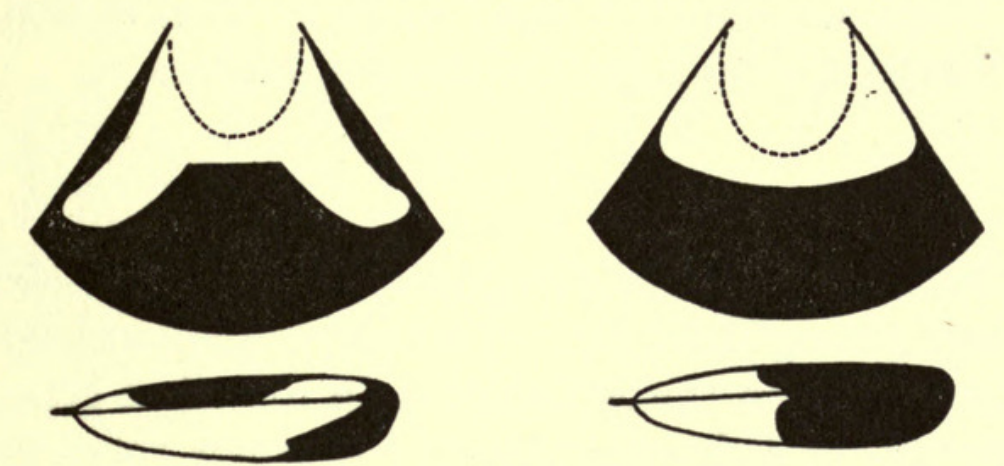

FIG. 5. Diagrammatic sketches to show colour-patterns of tails and outermost tail feathers of left, Ducula bicolor; right, Columba argentina.

Ducula than to Columba. I have been unable to find any description of the anatomy of this pigeon which would show whether its stomach and intestines are of Ducula or Columba type. From its plumage characters, I think, however, that it is rightly placed in Columba. It shows the same type of sexual dimorphism-female a slightly duller and browner grey-in plumage colour as do other grey Columba species. It resembles punicea in the colour-pattern of its wings although the coloration of the two is different. Superficially the tail appears to be similarly marked to that of the Pied Imperial Pigeon but the pattern on the outer retrices (see Text-fig. 5) is quite different. I think, therefore, that argentina's resemblance to the pied Ducula species is due to convergence and that it is best regarded as a rather aberrantly coloured member of the Elphinstonii species-group. It is another example of a Columba species which appears to have lost the display plumage on the neck, a point compatible with its presumed affinity to punicea which appears to show a regressional stage of this display plumage.

\section{C. palumboides}

In appearance, at least of the skin, the Andaman Wood Pigeon suggests a link between the Elphinstonii and Janthina species-groups. It seems likely to be nearer 
to the former on geographical grounds. Hume (I867) who collected some specimens and had a captive bird under observation was impressed by its " mode of holding itself and its broad substantial body" which he considered argued relationship to Ducula rather than to Columba. This may not be of importance as in so far as it is adapted to an arboreal life; any large pigeon is bound to show some resemblance to Ducula as indeed does the common Wood Pigeon palumbus. A comparison of the alimentary tracts and a comprehensive study of the foods taken by this and other very arboreal Columba species with those of the Ducula species living in the same regions would be of great value.

\section{C. janthina}

The Black or Japanese Wood Pigeon and C. vitiensis, seem best considered as members of a single superspecies. $C$. $j$. nitens with its distinctive purple-brown head is somewhat intermediate, but in most respects is closer to nominate janthina than to any race of vitiensis. Stresemann (I939) suggests New Guinea as the place of origin of these forms and gives a map of their distribution and the probable directions of their former spread from the Papuan regions.

\section{C. vitiensis}

Although generally arboreal, so far as is known, $C$. v. halmaheira has been recorded nesting on the ground among thick cover (Warner, I949) and Mr. I. C. J. Galbraith informs me that the natives on the Solomons told him that ground nesting was not infrequent in this species. In its bowing display (Newman, I9I0) the bird moves rather slowly and does not erect its tail.

\section{C. norfolciensis}

This species appears to be a derivative of vitiensis. Males differ strikingly from the parent species in having the head and underparts white, or, in new plumage, creamy buff with a pink tinge. Females, however, have these parts whitish-grey or greyish-buff with some iridescence on the crown of the head and the pale throatas in vitiensis - almost pure white and fairly clearly demarcated. Whether norfolciensis merits specific recognition is arguable but in view of the great difference in the appearance of the males, which makes it highly likely that if at some future period it were to invade the range of vitiensis or vice versa the two would not interbreed, and the nomenclatorial changes that would be involved, it seems preferable to accord it specific rank within the same superspecies.

\section{C. versicolor}

This extinct species appears to have been a very close relative of janthina. Kuroda (I925) considers it a race of janthina. Both forms occurred, however, on the Bonin Islands and I think therefore that Peters (I937) was right to give them specific rank in spite of their obvious affinities in form and coloration. 


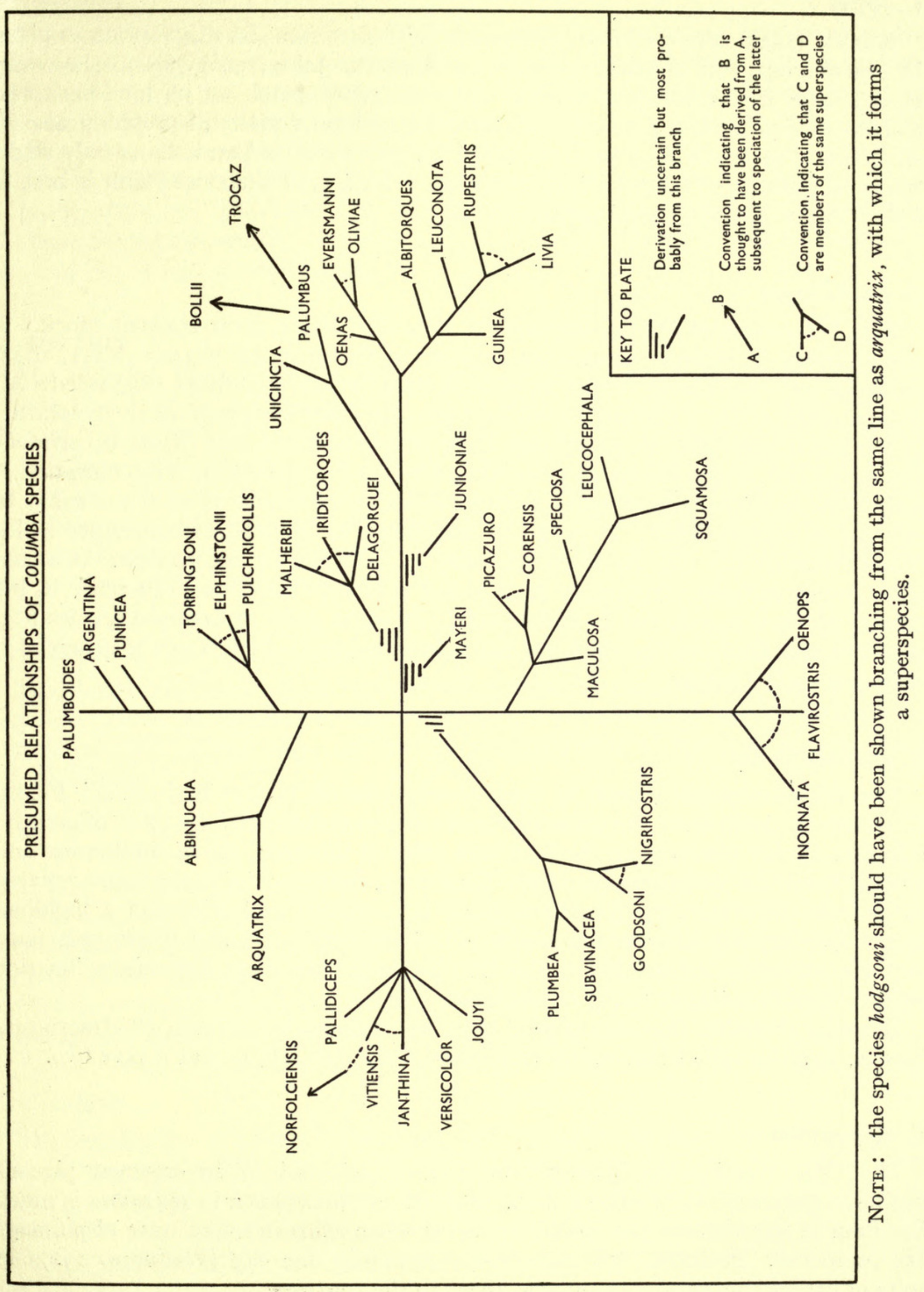




\section{C. jouyi}

Kuroda (I925) considers jouyi conspecific with janthina. Its distribution as given by him overlaps with nominate janthina on Okinawa. Jahn (I940) does not, however, record jouyi from Okinawa. Besides the large silver patch on its hind-neck and mantle-which presumably functions as a recognition mark and probably also as an isolating mechanism-jouyi is a larger, longer-tailed bird and shows only slight traces of iridescence other than on the neck and nape. I therefore think it best to follow Peters in giving jouyi specific status.

\section{C. pallidiceps}

The Yellow-legged Pigeon appears to be a derivative from vitiensis stock. It now overlaps $C$. vitiensis halmaheira on some of the Solomon Islands (Mayr, I934) although only pallidiceps occurs in New Britain, where it perhaps originated. Although much alike in general appearance the two differ strikingly in the coloration of the head, silver-grey in pallidiceps, dark purple with a white throat in vitiensis; and in the feet, which are red in vitiensis and yellow in pallidiceps. The coloration of pallidiceps is suggestive of that of norfolciensis (q.v.) whose close relationship to vitiensis is beyond doubt. It would be interesting to know if the difference in leg colour between the two serves in any way as an isolating mechanism. It would seem rather unlikely particularly as it is not correlated with any difference in bill colour, which is mainly red in both species. In other pairs of Columba species (e.g. arquatrix and albinucha) in which one has yellow and one red legs there is a correlated difference in bill colour.

\section{C. leucocephala}

The White-crowned Pigeon is very closely related to the Red-necked Pigeon C. squamosa. Both have the same highly-developed and beautifully (but differently) coloured display plumage on the back and sides of the neck, are of similar size and inhabit the same geographical areas. They may, however, be ecologically isolated as in Cuba (Barbour, I943); leucocephala is a coastal and squamosa a highland form. The striking difference in coloration of the head, eyes and display plumage in these otherwise almost identical forms suggests that these differences function or have functioned as isolating mechanisms.

It seems probable that this pigeon lays but one egg to a clutch (Wetmore and Swales, I93I) in spite of an earlier statement (Gundlach, I874) that it lays two.

\section{C. squamosa}

The close relationship between the Red-necked and White-crowned pigeons has been discussed under leucocephala. The sexual dimorphism in squamosa is much less than in leucocephala but readily apparent when skins in a like state of plumage are compared. Probably this pigeon also lays only one egg (Wetmore, 1927) in spite of earlier statements (Gundlach, I874) to the contrary. 


\section{C. speciosa}

The Scaled Pigeon appears to be fairly close to squamosa and leucocephala. In some respects its plumage is intermediate between that of these species and of picazuro but I do not agree with Verheyen that speciosa and picazuro should be generically separated from squamosa and leucocephala. In speciosa the dark edgings to the feathers are found throughout most of its plumage but are intensified in contrast and brilliance on the neck, thus giving a suggestion of the condition obtaining in leucocephala and squamosa. The Scaled Pigeon shows strong sexual dimorphism, the male having the mantle and wing-coverts rich purple (fading to chestnut) whereas those of the female are dull brown.

\section{C. picazuro}

The Picazuro Pigeon has the display plumage on the neck less highly developed than in leucocephala and squamosa but of an essentially similar kind. According to Hudson (I920) its habits, gait and behaviour are similar to those of palumbus but except for a vivid contrast of its gait on the ground with that of maculosa he gives no details. Hudson said that it lays two eggs, Venturi (see Hartert, I909) that sometimes one and sometimes two eggs are laid. Wetmore (I926) found a nest with one egg. He also said that the display flight is like that of livia, a rather surprising fact in an essentially woodland species.

\section{C. corensis}

The Bare-eyed Pigeon can be considered as forming a superspecies together with picazuro. Its main differences, the much paler coloration and the very extensive amount of bare orbital skin, are probably adaptations to the hot, coastal areas where it lives.

\section{C. maculosa}

I think the Spotted Pigeon is most closely related to picazuro. It has evidently become more fully adapted to feeding on the ground in open country. Its resemblance in wing/tail proportions and gait to livia is almost certainly due to convergence in feeding habits. This is another species which has no display plumage on the neck, probably having lost it at a relatively recent date. If so, no close relationship to other species sharing this negative character is indicated.

\section{C. fasciata}

The Band-tailed Pigeon is reminiscent of $C$. arquatrix in its yellow bill and feet. The pattern of the bill is unusual in adult Columba but very much like that of Columba nestlings, only the dark sub-terminal band having " spread " to the tip of the bill and the lighter base turned bright yellow. The copulation ceremony of this species (Whitman, I9I9) evidently differs in several details from that of European Columba species. 


\section{C. araucana}

Although the Chilean Pigeon is very closely related to the southern form of the Band-tailed $C$. fasciata albilinea it has, I think, diverged sufficiently to be given specific rank. Besides the plumage differences (purplish-maroon on mantle and scapulars) it has a dark bill and red legs. It can be considered as forming a superspecies together with fasciata and caribaea.

\section{C. caribaea}

The Jamaican Band-tailed Pigeon is clearly derived either from fasciata, araucana or from some comparatively recent form ancestral to them both. In plumage it differs from fasciata only in being paler, in having lost the white neck-ring and having less well developed iridescent display plumage on the neck. It differs also in having, like araucana, a dark bill and red legs.

\section{C. cayennensis}

The Rufous Pigeon is intermediate in many respects between the members of the "fasciata" superspecies and those of the superspecies " flavirostris". It resembles the former in the colour-pattern of its tail feathers and in having display plumage on the hind neck but in its other plumage characters it is closer to flavirostris. Little or nothing seems to be recorded about its breeding habits in the wild but two clutches of one egg each were laid by captive specimens (Newman, I9ro).

\section{C. flavirostris}

The Red-billed Pigeon forms a superspecies together with oenops and inornata. All three completely lack display plumage on the neck thus presenting a superficial resemblance to the Oenoenas species.

\section{C. oenops}

This is the Peruvian representative of flavirostris. In appearance it differs only in the colour of its bill, which is yellow, or yellow tipped with black, instead of pink and whitish. Also the males have a larger area of ruddy purple on the plumage of the upper parts but females and juveniles are intermediate in this respect between males of their own species and favirostris.

\section{C. inornata}

This island representative of flavirostris differs only in its larger size, black bill and grey, instead of red, orbital skin.

\section{The Sub-genus Oenoenas}

Salvadori (I893) characterized this sub-genus as having "general plumage, brown, more or less vinous, and with no light spots on the neck, but sometimes with concealed reddish spots, more or less obsolete, on the hind-neck". Actually the "reddish spots" are appreciably lighter than the adjacent areas of the feathers 
that show them and these pigeons also have, as pointed out by Ridgway (I9I6), rather small bills and strongly rounded tails. Ridgway gave them, and others less deserving, full generic rank but subsequent authorities (Peters, I937; Hellmayr \& Conover, I942 ; de Schaunsee, I948) put Oenoenas into the synonymy of Columba.

The four species concerned, plumbea, subvinacea, nigrirostris and goodsoni are all closely related and are more sharply differentiated than any others within Columba, mayeri excepted. I do not concur with Boetticher in considering them to be closely related to caribaea or that their dull concolorous plumage represents the retention of a primitive condition. The Oenoenas species differ from other American pigeons (except for the quite differently coloured speciosa) in lacking grey on the rump, which is concolorous with the mantle and wings or nearly so. The more or less obsolescent pale or bronzy-red markings on the feathers of the hind-neck are more prominent in females than in males, which suggests that so far from representing display plumage in process of acquisition, as Boetticher suggests, the reverse is the case. 'The obsolescent display plumage and general dull coloration of Oenoenas seems to be, in the evolutionary sense, a relatively recent development, not the retention of primitive characters.

Oenoenas is most probably an early offshoot from the other American Columba that has diverged considerably from the parent stock. Its sombre, concolorous dress with complete lack of signal markings and obsolescent display plumage presumably evolved as a consequence of increased predator pressure consequent on smaller size and/or increased reliance on vocal differences as isolating mechanisms.

\section{C. plumbea and C. subvinacea}

Only the fact that these pigeons appear to be sympatric in parts of their range. makes it possible - on present knowledge-to consider them as specifically distinct. Whilst the slight differences of colour and bill size make it possible to identify most specimens, it is difficult to believe that they could be sufficient to act as isolating mechanisms for the birds themselves. Presumably vocal and behavioural differences exist, but they do not appear to have been recorded. A few specimens in the National Collection are intermediate in character between plumbea and subvinacea but it is impossible to say whether these are hybrids or merely individuals whose slight aberrancy is towards the characters of the other species.

\section{C. nigrirostris and $C$. goodsoni}

These can certainly be regarded as forming a single superspecies. They may well be conspecific but since their taxonomic differences are at least as great (or one might better say no less) than those of plumbea and subvinacea, it seems better to grant them specific rank until more is known about them.

\section{The Sub-genus Turturoena}

This is comprised of three allopatric species delagorguei, iriditorques and malherbei which replace one another geographically and can be considered as forming a single superspecies. Salvadori (I893) separated Turturoena generically from Columba 
on its smaller size, hind neck with bright metallic colours and the sexes being often very dissimilar. Subsequent authorities have disagreed about its status, Peters (I937) placing it in the synonymy of Columba and Cave \& Macdonald (I955) and Mackworth-Praed \& Grant (I952) giving it full generic rank. I think, personally, that the differences do not merit more than sub-generic rank within Columba.

Boetticher considers that Turturoena is more closely related to Aplopelia than to Columba. Certainly all three species have a similar distribution of iridescence to that of the Aplopelia species (but one found also in some species of Columba, and other pigeons) and a similar degree and type of sexual dimorphism. However, in my opinion, they show more affinities to the Columba species, not only in their general appearance but also in their colour-patterns which much resemble those found in palumbus and allied species. Mr. R. E. Moreau informs me (in litt.) that the cooing of delagorguei sharpei in Tanganyika reminded him very much of that of the Wood Pigeon, palumbus.

\section{The Sub-genus Nesoenas}

Salvadori (1893) placed the Mauritius Pigeon, C. mayeri, in the monotypic genus Nesoenas because of its more rounded wing, with the first primary about equal in length to the sixth, and its rufous tail. In coloration this pigeon does not closely resemble any other Columba but its colour-pattern shows some resemblance to the oenas species-group, from which it may possibly be an offshoot. Fortunately this species is not extinct as was at one time feared so it is possible that studies of it that will serve to indicate its affinities may yet be made. In the meantime I think it is better to put Nesoenas as a sub-genus within Columba than to afford it generic rank.

\section{S UMMARY}

This paper revises the genus Columba. The taxonomic and behavioural characters of the species are discussed in reference to their probable affinities.

The absence or obsolescence of the display plumage on the neck is never a primitive character in Columba but one that has evolved independently in several species.

Oenoenas, Turturoena and Nesoenas are given sub-generic rank. It does not seem feasible to further sub-divide the genus. There are indications that the American species may prove separable on anatomical and biochemical criteria although they cannot be separated on external characters.

\section{REFERENCES}

AlI, S. I949. Indian Hill Birds. Oxford (p. I73).

Austin, O. L. 1948. The Birds of Korea. Bull. Mus. Comp. Zool. 101 (I) : I-I3o.

Baker, E. C. Stuart. r9i3. Indian Pigeons and Doves. London.

Barbour, E. 1943. Cuban Ornithology (Mem. Nuttall. Orn. Club. no. 9, pp. 70-72).

Boetticher, H. von. 1954. Die Taubengattung Columba L. Zool. Anzeiger, 153, 3-4:49-64.

CAIN, A. J. 1954. Subdivisions of the genus Ptilinopus. Bull. Brit. Mus. (Nat. Hist.) Zool. 2, No. 8. 
Cave, F. O. \& Macdonald, J. D. I955. Birds of the Sudan. London.

Cumley, R. W. \& Irwin, M. R. 1944. The correlation between antigenic composition and geographic range in the Old and New World of some species of Columba. Amer. Nat. LXVIII, No. $776: 238-256$.

Dementiev, G. P. et al. I951. Birds of the Soviet Union, $11: 6-32$.

Goodwin, D. I956. Remarks on the Rock and Speckled Pigeons. Bull. Brit. Orn. Club, 76 : 6-9. I956a. Observations on the voice and displays of certain pigeons. Avic. Mag. 62: 17-33 and $62-70$.

Gundlach, J. I874. Neue Beitrage zur Ornithologie Cubas. Journ. Orn. I874: 289.

Hartert, E. \& Venturi, S. I909. Notes sur les oiseaux de la Republique Argentine. Novit. Zool. XVI, No. 2 : 260-26I.

Hellmayr, C. E. \& Conover, B. I942. Catalogue of Birds of the Americas, pt. I, no. I, Zool. Ser. Field Mus. Nat. Hist. XIII, pt. I, No. I.

Hudson, W. H. 1920. Birds of La Plata. Vol. 2, pp. I54-I55.

JAHN, H. 1942. Zur Oekologie und Biologie der Vögel Japans. Journ. Orn. 90, I-2 : 7-30I.

La Touche, J. D. D. 1934. A handbook of the birds of Eastern China. Vol. 2, p. 209. London.

Kuroda, N. 1925. A contribution to the knowledge of the avifauna of the Riu Kiu Islands and the vicinity. Tokyo.

Mackworth Praed, C. W. \& Grant, C. H. B. I952. The African handbook of Birds: Ser. I, vol. I, p. 468.

Mayr, E. I93I. The birds of Malaita Island. Amer. Mus. Novit. 504, No. I Ith, I931, p. Io.

- 1934. Notes on some birds from New Britain, Bismarck Archipelago. Ibid. 709, 4th April, I934, pp. 4-5.

Meade-Waldo, E. G. I889. Notes on some birds of the Canary Islands. Ibis, 6th Ser. No. I, pp. 6-9 and No. 4, pp. 509-510.

Miculicz-RAdEcki, M. von. I949. Betrachtungen zur Stammesgeschichte der Wildtauben. Verhand. Deutsch. Zool., Aug. I949, pp. 55-66.

Newman, T. H. I9Io. Nesting of the White-throated Pigeon. Avic. Mag. 3rd Ser., vol. I, No. 5, pp. $15^{8-164}$ and $193-195$.

I9II. The Snow Pigeon. Ibid. Vol. 2, No. 6, pp. I73-178.

Peters, J. L. I937. Check-list of the Birds of the World. Vol. 3. Camb. Mass. U.S.A.

Pollen, P. L. \& VAN DAM, D. C. I868. Recherches sur la Faune de Madagascar et ser Dependences. Vol. 2, pp. II2-II3. Leiden.

Salvadori, T. I893. Catalogue of Birds in the British Museum. Vol. 2 I.

SchäfER, E. I938. Ornithologische Ergebnisse zweier Forschungsreisen nach Tibet. Journ. $f$. Orn. Supplement, May 1938.

Schaunsee, R. M. DE. I948. The Birds of the Republic of Columbia, part I. Bogotá.

Sibley, C. G. I957. The evolutionary and taxonomic significance of sexual dimorphism and hybridisation in birds. Condor 59:3: pp. I66-191.

TAibell, A. M. 1954. Notizie sulla riproduzione in cattivatá del Colombo dal collare bianco (Columba albitorques). Rivista It. Orn., I954 (Seconda serie), pp. 195-203.

Van Someren, V. G. L. I949. The birds of Bwamba. Special supplement to the Uganda Journal, Vol. I3, pp. 24-25.

Verheyen, R. I955. Le Pigeon Bleu (Columba arquatrix Temm.) du Ruwenzori. Le Gerfaut, 1955, vol. 2, pp. I27-I 45 .

- I957. Analyse du potential morphologique et project de classification des columbiformes (Wetmore, 1934). Bul. Inst. Roy. Sci. Bel. Vol. 33, No. 3.

WARner, D. W. I949. The White-throated Pigeon nesting on the ground in New Caledonia. Auk. 66 : 90-91.

Wetmore, A. 1927. The birds of Porto Rico, pp. 390-391.

Wetmore, A. \& Swales, B. H. I93I. The birds of Haiti and the Dominican Republic. U.S. Nat. Mus. Bull. 155 : 184.

Whitman, C. O. I9I9. The behaviour of pigeons. Posthumous works of C. O. Whitman. Vol. 3: pp. 56-57. Carnegie Inst., Wash.

zool. 6 , I. 


\section{$2 \mathrm{BHL}$ Biodiversity Heritage Library}

Goodwin, Derek. 1959. "Taxonomy of the genus Columba." Bulletin of the British Museum (Natural History) Zoology 6, 1-23. https://doi.org/10.5962/bhl.part.26842.

View This Item Online: https://www.biodiversitylibrary.org/item/19530

DOI: https://doi.org/10.5962/bhl.part.26842

Permalink: https://www.biodiversitylibrary.org/partpdf/26842

\section{Holding Institution}

Natural History Museum Library, London

\section{Sponsored by}

Natural History Museum Library, London

\section{Copyright \& Reuse}

Copyright Status: In copyright. Digitized with the permission of the rights holder.

Rights Holder: The Trustees of the Natural History Museum, London

License: http://creativecommons.org/licenses/by-nc-sa/4.0/

Rights: http://biodiversitylibrary.org/permissions

This document was created from content at the Biodiversity Heritage Library, the world's largest open access digital library for biodiversity literature and archives. Visit BHL at https://www.biodiversitylibrary.org. 